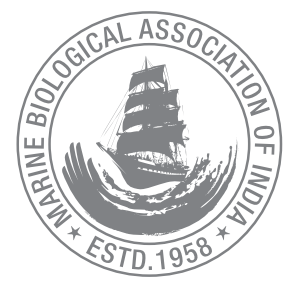

\title{
Fishery and population dynamics of Epinephelus malabaricus (Bloch \& Schneider, 1801) off Tuticorin, southeast coast of India
}

\author{
P. P. Manojkumar*, L. Ranjith, K. Karuppasamy and K. P. Kanthan \\ Research Centre of ICAR- Central Marine Fisheries Research Institute, South Beach Road, Tuticorin, India - 628001. \\ *Correspondence e-mail: manojppin@yahoo.com
}

Received: 17 Dec 2018 Accepted: 25 June 2019 Published: 30 June 2019

Original Article

\begin{abstract}
Fishery, population characteristics and stock estimates of grouper with special reference to Epinephelus malabaricus from Tuticorin were carried out during 2015-2017. Among the groupers, E. malabaricus was the dominant resource contributing $42.2 \%$, with an annual average production of $420 \mathrm{t}$ along this region. The asymptotic length $\left(L_{\infty}\right)$, growth coefficient $(K)$ and arbitrary origin of growth $\left(\mathrm{t}_{0}\right)$ were estimated at $99.75 \mathrm{~cm}, 0.53 \mathrm{y}^{-1}$ and 0.18 respectively. The mortality parameters, the instantaneous total mortality rate (Z), fishing mortality (F) and natural mortality rates (M) were estimated at $1.14 y^{-1}, 0.62 y^{-1}$ and $0.52 y^{-1}$ respectively. The recruitment season was during April to August. The length structured virtual population (VPA) analysis revealed a heavy fishing pressure on length group between 40 and $55 \mathrm{~cm}$ and there is no sign of recruitment over-fishing in this region. The estimated maximum sustainable yield (MSY) and annual catch were $384 \mathrm{t}$ and $420 \mathrm{t}$ respectively. E. malabaricus was optimally exploited as the exploitation ratio (E) was 0.54 but the study infers that further increase in effort may have a detrimental effect on the stock of this species. The results of this study will serve as baseline information for formulating future management measures for the resource along the coast.
\end{abstract}

Keywords: Grouper, growth parameters, mortality parameters, MSY, recruitment overfishing.

\section{Introduction}

The family Serranidae is a diverse group of fishes, of which the genus Epinephelus commonly known as groupers is the largest one with several species. Groupers are commonly caught in reef areas of tropical and warm-temperate latitudes and are targeted because of their tasty flesh and high value in the live export trade. The Malabar grouper, Epinephelus malabaricus (Bloch and Schneider, 1801) is listed in the International Union for the Conservation of Nature (IUCN) as data deficient (Samoilys et al., 2018). It is one of the largest and most common grouper found in the Red Sea, the Indo-Pacific region, Southeast Asia and Australia (Murata et al., 2010). The adults of this species are found in a variety of habitats, including coral and rocky reefs, tide pools, estuaries, mangrove swamps and sandy/muddy bottom from the shore to depths of $150 \mathrm{~m}$, while juveniles are found near shore and also in estuaries (Heemstra and Randall, 1993). E. malabaricus primarily feeds on fishes and crustaceans and occasionally on cephalopods and are mainly caught in 
trawls, long lines, traps, spear and hook-and-line (Heemstra and Randall, 1993; Kirubasankar et al., 2013).

E. malabaricus has a complex life-history and is a protogynous hermaphrodite. Sexual maturity in males does not occur until they are $114 \mathrm{~cm}$ long (Lau and Li, 2000) and do not change sex from female to male until 10 years of age (Murata et al., 2010). Moreover, this species has a very low resilience to fishing, with a minimum population doubling time of more than 14 years (Froese and Pauly, 2018). In Indian waters, stock estimates and studies on different grouper species were done by several authors (Premalatha, 1989; Ameer and Kasim, 1992; Chakraborty, 1994; Rangaswamy et al., 1999; Manojkumar, 2005; Sivakami and Seetha, 2006; Jayasankar et al., 2007; Sujatha et al., 2010; Kirubasankar et al., 2013). Studies on population dynamics and stock characteristics of genus Epinephelus were done by very few authors (Manojkumar, 2005; Mehanna et al., 2013; Richu et al., 2018). However, information on the stock assessment more specifically on $E$. malabaricus from Indian waters is scanty with an exception of a publication by Kirubasankar et al. (2013) from the Andaman Islands. Growth, mortality and recruitment studies are key parameters for assessment of a fish stock (Manojkumar, 2005). Hence, a study was undertaken to assess the stock status of E. malabaricus and the impact of fishing pressure on this important species exploited along this region. This attempt on the fishery and stock assessment of E. malabaricus from Gulf of Mannar, southeast coast of India is the first of its kind in the Indian mainland.

\section{Material and methods}

The data pertaining to the catch and effort of groupers including E. malabaricus from different gears operating in Tuticorin for eight years from 2010 to 2017 were collected from the Fisheries Resource Assessment Division, ICAR-Central Marine Fisheries Research Institute (CMFRI). The data on the length frequency distribution of $E$. malabaricus comprising 1,675 specimens were collected for a period of three years from 2015 to 2017 through a random sampling technique on a weekly basis following Alagaraja (1984) and for stock assessment studies the samples were collected from the Hook and Lines $(\mathrm{H} \& \mathrm{~L})$ operating along the Tuticorin coast as the bulk of the catch was landed from this gear. Length frequencies were raised to correspond to the weight of the catch assessed for the day and subsequently for the month following Sekharan (1962). The age and growth were assessed using the FiSAT computer software II (Gayanilo et al., 2005). The asymptotic length $\left(\mathrm{L}_{\infty}\right)$, growth coefficient $(K)$, recruitment pulses and arbitrary origin of growth $\left(\mathrm{t}_{0}\right)$ values were analyzed by non-parametric scoring of von Bertalanffy growth function (VBGF) fit using ELEFAN-1. The total mortality rate (Z) was estimated by the length converted catch curve method (Pauly, 1983) using FiSAT. The natural mortality (M) was estimated by Pauly's equation considering the mean annual temperature (Pauly, 1984). The coefficient of fishing mortality (F) was derived by using the relationship, $\mathrm{F}=$ Z-M. The length structured VPA of FiSAT was used to find out the size of each length group of $E$. malabaricus, their natural and fishing mortality. The annual stock, $(B=\mathrm{Y} / \mathrm{F})$ was estimated using annual catch where, $Y$ is Yield, and $F$ is fishing mortality. The Maximum Sustainable Yield (MSY) was estimated using the equation described by Gulland (1959) for exploited fish stock, MSY $=\mathrm{Z} \times 0.5 \times \mathrm{B}$. Yield isopleth diagrams of $E$. malabaricus were derived by FiSAT using $\mathrm{L}_{50} / \mathrm{L}_{\infty}$ and $\mathrm{F} / \mathrm{Z}$ value.

\section{Results and discussion}

\section{Craft and Gears}

The gears in which E. malabaricus landed along the Tuticorin coast are the mechanized trawl fleet consisting of 12-28 m length overall (OAL) fitted mostly with $150 \mathrm{HP}$ engines or even more was operated for single day fishing in this region. The boats are designed for stern trawling with power winches. The gear employed consisted of two or four-seam trawls with the head rope length ranged from 12 to $15 \mathrm{~m}$ and the cod end mesh size ranged from 15 to $30 \mathrm{~mm}$. The fishing operation was carried out up to a depth of $120 \mathrm{~m}$ or even more. For gill net operation, motorized plank built wooden or FRP boats fitted with inboard or outboard engine with the OAL 8 to $12 \mathrm{~m}$ fitted with 9.9 to $110 \mathrm{HP}$ engines are used along Tuticorin coast. The mesh size of gear ranged from 85 to $145 \mathrm{~mm}$. Fishing is either single day or multiday and fishing operation is carried out up to a depth of $60 \mathrm{~m}$. Handlines and longlines were mostly operated by the fishermen of Therespuram, Amali Nagar, Iniconagar and Kombudurai fishing villages. Therespuram fishermen operate longlines seasonally, mainly during November to May; Kombudurai and Iniconagar fishermen operate longlines from January to August whereas the Amalinagar fishermen operates throughout the year. The craft OAL is 8 to $10 \mathrm{~m}$ fitted mostly with outboard engines with 9.9 to $15 \mathrm{HP}$. The main line length was from 2000 to $6000 \mathrm{~m}$ with 100 to 150 branch lines for longlines whereas for handline, the main line length was from 50 to $120 \mathrm{~m}$. 'J' type hooks with the hook numbers ranging from 4 to 8 were used.

\section{Fishery}

The result of the study conducted showed that from Tuticorin coast, E. malabaricus supports an important and a dominant fishery whereas other grouper species occur in small quantities in the catch. The highest landing of grouper was recorded in $2015(1201 \mathrm{t})$, thereafter the fishery has shown a declining trend. The annual estimated landings of grouper during 2010-2017 varied from of $725 \mathrm{t}$ (2014) to $1201 \mathrm{t}$ (2015) with an average 
contribution of $905 \mathrm{t}$ constituting $10 \%$ of the total catch (Fig. 2). The landing of these resources by hook and line fishing at Tuticorin accounted for nearly $59 \%$ of the exploited total groupers along the coast. The fishery along the coast does not form any pattern and it showed wide fluctuations during the seven-year period. The average annual of $E$. malabaricus contribution to total grouper landings in the trawl net, gill net, $\mathrm{H} \& \mathrm{~L}$ and other gears were $22.0 \%, 27 \%, 50.0 \%$, and $1.0 \%$ respectively.

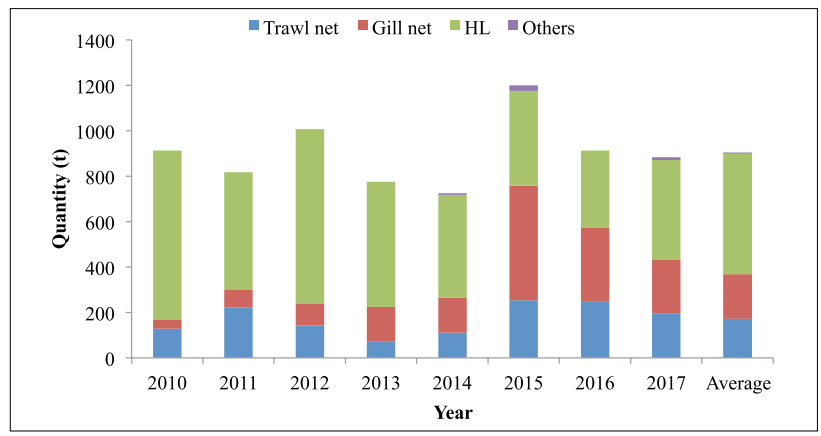

Fig. 1. Gearwise annual landings (t) of groupers in Tuticorin

\section{Species composition}

In total, seventeen species of groupers were recorded during the study period (Fig. 2). They were Epinephelus malabaricus (42.2\%), E. bleekeri (11.0\%), E. longispinis (8.1\%), E. undulosus (8.0\%), E. fuscoguttatus $(5.0 \%)$, E. coioides $(5.0 \%)$, Cephalopholis urodeta $(4.0 \%)$, C. formosa $(4.0 \%)$, C. miniata $(0.2 \%)$, E. areolatus $(3.0 \%)$, E. merra $(2.0 \%)$, E. faveatus $(2.0 \%)$, E. fasciatus $(2.0 \%)$, E. coerleopunctatus $(0.8 \%)$, E. flavocaeruleus

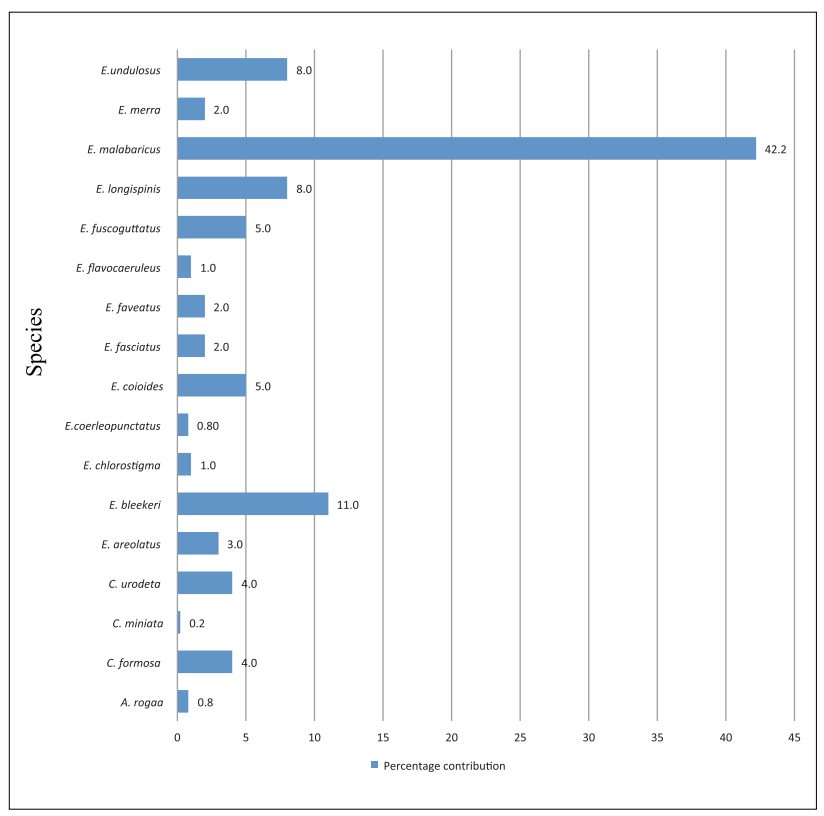

Fig. 2. Species composition of groupers in Tuticorin
(1.0\%), E. chlorostigma (1.0\%), and Aethaloperca rogaa (0.8\%). Among all the species of grouper occurring along the Tuticorin coast, E. malabaricus was the dominant species. In India, thirty-eight species of groupers have been reported from the seas wherein the $E$. malabaricus is a common species along the west coast of India and in the Gulf of Mannar (James et al., 1996) as observed in the present study.

\section{Catch rate}

The annual average catch rate of grouper in trawl net ranged between $0.35 \mathrm{~kg}$ per $\mathrm{hr}$ (2010) and $0.72 \mathrm{~kg}$ per hr (2015) with an average of $0.46 \mathrm{~kg}$ per hr. In gill net, the catch rate fluctuated between $0.13 \mathrm{~kg}$ per unit (2010) and $2.14 \mathrm{~kg}$ per unit (2015) whereas in hook and line the catch rate ranged between $5.07 \mathrm{~kg}$ per unit (2014) and $8.90 \mathrm{~kg}$ per unit (2010) with an average of $7.07 \mathrm{~kg}$ per unit. Overall, the catch rate has shown a declining trend from 2014 to 2015 but showed a slight increase in 2017 (Fig. 3). A comparison of effort, catch and catch rate showed that even though the effort increased there was no such corresponding trend in the catches of groupers during most of the study period. Sujatha et al. (2010) reported that E. malabaricus were represented both in traditional gear and trawl catches of the north Andhra region, large-size specimens of these species were also caught with hook and line from deeper waters but does not show any trend in the landings.



Fig. 3. CPUE $(\mathrm{Kg})$ of groupers in Tuticorin

\section{Age and Growth}

In the present study, multiple modes could be seen in the monthly length frequency data and traceable modes for two consecutive months were used to assess the growth of cohorts from 2015 to 2017 of E. malabaricus. The von Bertalanffy's 
Growth Function (VBGF) plot is given in Fig. 4. The estimated growth parameters, ie., asymptotic lengths $\left(\mathrm{L}_{\infty}\right)$ and growth coefficient (K), were $99.75 \mathrm{~cm}$ and $0.53 \mathrm{y}^{-1}$ respectively. The estimated maximum lifespan was found to be 9 years. Kirubasankar et al. (2013) got higher values from Andaman Islands and the estimated growth parameters from length data of $E$. malabaricus landed on Andaman Islands were, $\mathrm{L}_{\infty}$ $=124.60 \mathrm{~cm}$ and $\mathrm{K}=0.80 \mathrm{y}^{-1}$. The factors explaining the relationship between the natural mortality coefficient and the growth coefficient $(M / K)$ obtained in the present study were 0.98 and it is well within the normal range of 1 to 2.5, as suggested by Beverton and Holt (1959). The generalized VBGF growth equation is $L_{t}=99.75\left\{1-e^{-0.53(t-0.18)}\right\}$

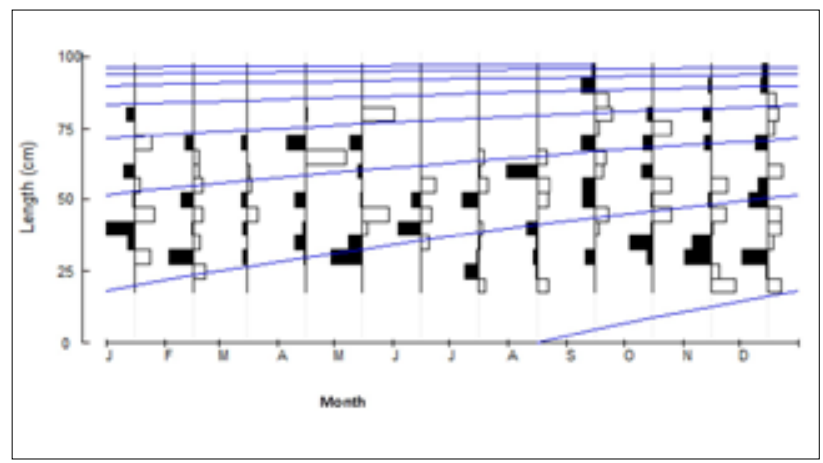

Fig. 4. von Bertalanffy's Growth function (VBGF) plot of E. malabaricus exploited off Tuticorin

\section{Mortality, virtual population analysis, and recruitment pattern parameters}

The mortality parameters, exploitation ratio and exploitation rate of $E$. malabaricus are given in Table 1 . The average natural mortality $(M)$ was found to be 0.52 . The average fishing mortality coefficient (F) was 0.62 and the estimated exploitation ratio (E) was 0.54 . The estimated $Z$ values of E. malabaricus by length converted catch curve method was 1.14. The calculated $Z$ and $M$ were lower when compared to the stock of the same species in Andaman waters. It could be inferred that fishing mortality was higher compared to natural mortality and the same trend was evident in Andaman waters (Kirubasankar et al., 2013).

Table 1. Mortality parameters and exploitation ratio of $E$. malabaricus of Tuticorin

\begin{tabular}{lllll}
\hline Year & $\begin{array}{l}\text { Natural } \\
\text { Mortality }(\mathrm{M})\end{array}$ & $\begin{array}{l}\text { Fishing } \\
\text { mortality }(\mathrm{F})\end{array}$ & $\begin{array}{l}\text { Total } \\
\text { instantaneous } \\
\text { mortality }(\mathrm{Z})\end{array}$ & $\begin{array}{l}\text { Exploitation } \\
\text { ratio (E) }\end{array}$ \\
\hline 2015 & 0.52 & 0.62 & 1.14 & 0.54 \\
\hline 2016 & 0.52 & 0.61 & 1.13 & 0.53 \\
\hline 2017 & 0.52 & 0.65 & 1.17 & 0.55 \\
\hline Average & 0.52 & 0.62 & 1.14 & 0.54 \\
\hline
\end{tabular}

The recruitment pattern of E. malabaricus showed a distinct peak with maximum recruitment during April-August contributing to $75 \%$ of total recruitment (Fig. 5). The highest recruitment took place in July (18\%) and the lowest in September (5\%). In Andaman waters, E. malabaricus recruited with a peak during April to July (Kirubasankar et al., 2013). However, in the present study, only one major peak season could be observed from June to July in Tuticorin coast. The major recruitment season coincides after the monsoon ban in the southeast coast of India. The results of the length structured Virtual Population Analysis (VPA) employed to recognize the level of mortality on various length groups are shown in Fig. 6 . The fishing pressure on $E$. malabaricus was more in the length group between 40 $\mathrm{cm}$ and $55 \mathrm{~cm}$. Higher fishing pressure was recorded in the terminal length group $(56.0 \mathrm{~cm}$ to $65.0 \mathrm{~cm})$ for E. malabaricus in Andaman waters (Kirubasankar et al., 2013).

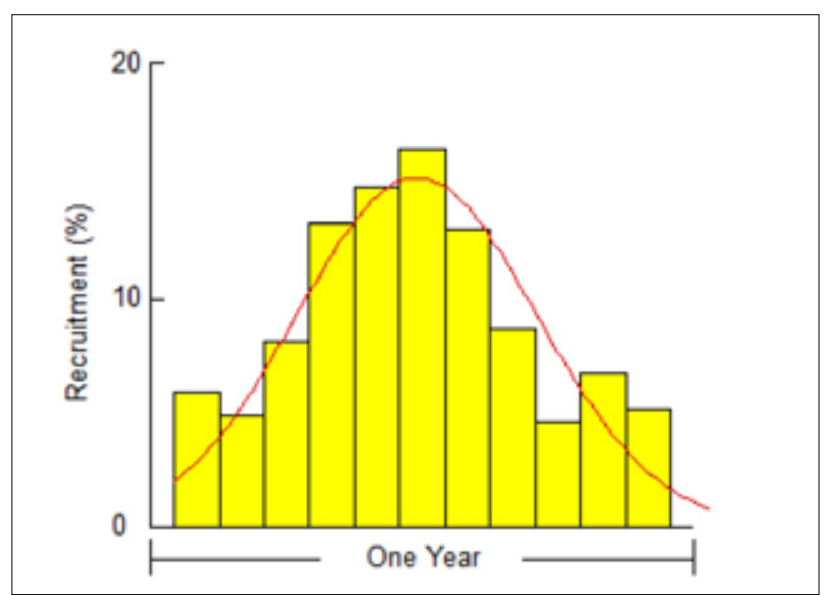

Fig. 5. Recruitment pattern of E. malabaricus off Tuticorin

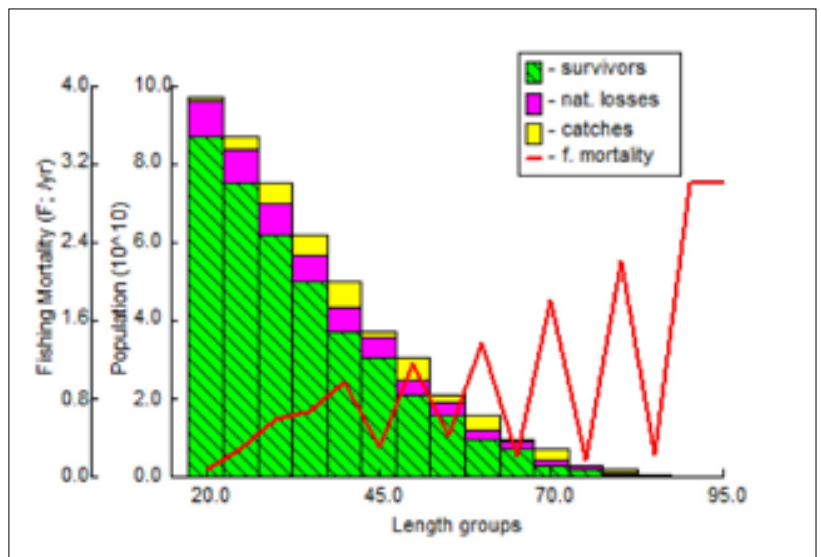

Fig. 6. Length structured Virtual Population Analysis of E. malabaricus exploited off Tuticorin

\section{Stock assessment}

The annual catch, annual stock and MSY estimated for E. malabaricus are presented in Table 2. The average estimated 
Table 2. Annual catch, annual stock and MSY of E. malabaricus of Tuticorin

\begin{tabular}{lllll}
\hline Year & $\begin{array}{l}\text { Annual catch } \\
(\mathrm{Y})(\mathrm{t})\end{array}$ & $\begin{array}{l}\text { Annual stock } \\
\mathrm{B}=(\mathrm{Y} / \mathrm{F})\end{array}$ & $\mathrm{t})$ & $\begin{array}{l}\text { Difference } \\
\text { between catch } \\
\text { and MSY }(\mathrm{t})\end{array}$ \\
\hline 2015 & 504 & 813 & 464 & 40 \\
\hline 2016 & 384 & 630 & 356 & 28 \\
\hline 2017 & 371 & 571 & 334 & 37 \\
\hline Average & 420 & 671 & 384 & 36 \\
\hline
\end{tabular}

MSY was $384 t$ and the annual catch was $36 t$ in excess of MSY. The MSY was lower compared to the result obtained for Andaman Island (Kirubasankar et al., 2013). The yield per recruit for E. malabaricus is shown in Fig. 8. The $\mathrm{L} / \mathrm{L}_{\infty}$ for the present exploitation ratio is 0.54 and it has been predicted that maximum yield is possible at the present level of exploitation. Yield isopleth is one of the prediction tools in stock assessment studies. The yield isopleths gives an idea about the present level of yield per recruit with the various possible combinations of exploitation rate (Gayanilo et al., 2005). The study suggests that yield of E. malabaricus marginally exceeded its MSY level, hence the effort may be maintained at the current level for the exploitation of this resource.

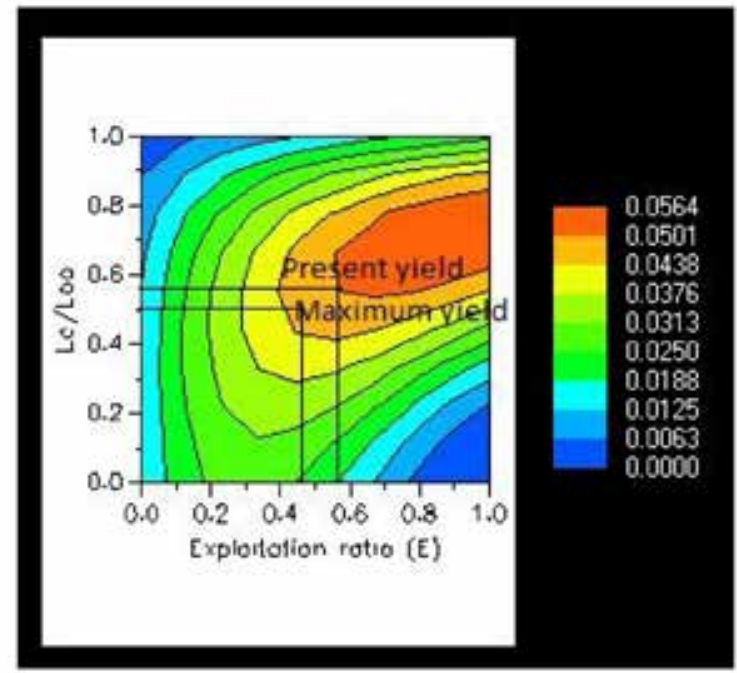

Fig. 7. Yield isopleths of E. malabaricus exploited off Tuticorin

\section{Acknowledgements}

The authors are thankful to Dr. P. U. Zacharia, Head, Demersal Fisheries Division and Dr. A. Gopalakrishnan, Director, ICARCMFRI, Cochin for their encouragements. The co-operation and help provided by the staff of the Tuticorin Research Centre of CMFRI are acknowledged with gratitude.

\section{References}

Alagaraja, K. 1984. Simple methods for estimation of parameters for assessing exploited fish stocks. Indian J. Fish., 31(2):177-208.

Ameer Hamsa, K. M. S. and H. Mohamad Kasim. 1992. Growth and production potential of young grouper Epinephelus tauvina (Forskal) reared in fixed net cages. J. Mar. Biol. Ass. India, 34(1\&2): 271-277.

Beverton, R. J. H. and S.J. Holt. 1959. A review of the lifespans and mortality rates of fish in nature, and their relation to growth and other physiological characteristics. In Ciba Foundation Symposium The Lifespan of Animals (Colloquia on Ageing). Chichester, UK: John Wiley \& Sons, Ltd. 5, p. 142-180.

Chakraborty, S. K. 1994. Age, growth, mortality and stock assessment of Epinephelus diacanthus (Valenciennes) from Bombay waters. CMFRI Bulletin-Perch fisheries in India, 47: 130-133.

Froese, R. and D. Pauly. 2018. Fish Base. World Wide Web electronic publication. www.fishbase.org, version (06/2018)

Gayanilo, F. C., P. Sparre and D. Pauly. 2005. FAO-ICLARM Stock Assessment Tools II. Revised Version. User's Guide. Worldfish Center, Rome. 168 pp.

Gulland, J. A and S. J. Holy. 1959. Estimation of growth parameters for data at unequal time intervals. J. Cons. Int. Explor. Mer., 25(1): 47-49.

Heemstra, P. C. and J. E. Randall. 1993. FAO Species Catalogue. Vol. 16. Groupers of the world (family Serranidae, subfamily Epinephelinae). An annotated and illustrated catalogue of the grouper, grouper, hind, coral grouper and lyretail species known to date. Rome: FAO. FAO Fish. Synop., 125(16): 382 pp.

James, P. S. B. R., V. S. Murty and P. Nammalwar. 1996. Groupers and snappers of India: biology and exploitation. Biology, fisheries and culture of tropical groupers and snappers, pp106-136.

Jayasankar, P., J. Jayasankar, C. Anand, and S. K. Augustine. 2007. Information on Epinephelus diacathus from Indian seas. Newsletter of the Groupers \& Wrasses Specialist Group, International Union for the Conservation of Nature, Gland, Switzerland, 10: 9-11.

Kirubasankar, R., S. Dam Roy, G. George, K. Sarma, P. Krishnan, S. Ramkumar and M. P. Goutham Bharathi. 2013. Fishery and Exploitation of Malabar Grouper, Epinephelus malabaricus (Bloch \& Schneider, 1801) from Andaman Islands. Asian Fish. Sci., 26:167-175.

Lau, P. P. and L. W. Li. 2000. Identification guide for fishes in the live seafood trade of the Asia-Pacific Region. WWF Hong Kong and Agriculture, Fisheries and Conservation Department. Hong Kong.142pp.

Manojkumar, P. P. 2005. Fishery of the spinycheek grouper, Epinephelus diacanthus (Valenciennes), off Calicut along the Malabar Coast. J. Mar. Biol. Ass. India, 47(1): 63-69.

Mehanna, S. F., A. Al-Marzouqi and C. El-Siabi. 2013. Stock characteristics and population dynamics of the spiny cheek grouper Epinephelus diacanthus (Valenciennes, 1828) from the Arabian Sea, Oman. Turk. J. Fish. Aquat. Sci., 13(1): 127-132.

Murata, R., H. Karimata, M. A. Alam and M. Nakamura. 2010. Precocious sex change and spermatogenesis in the underyearling Malabar grouper Epinephelus malabaricus by androgen treatment. Aquac. Res., 41(2): 303-308.

Pauly, D. 1983. Some simple methods for the assessment of tropical fish stocks. FAO Fisheries Technical Paper No. 234, 52 pp.

Pauly, D. 1984. Fish population dynamics in tropical waters: a manual for use with programmable calculators. ICLARM Studies and Reviews, (8): 325pp.

Premalatha, P. 1989. Fishery and biology of grouper (Order-Perciformes) from the southwest coast of India. Indian J. Fish. 36(4):285-291.

Rengaswamy, V. S., R. Marichamy, S. Rajapackiam and D. Sundararajan. 1999. Collection and transportation of groupers for farming. In: the Fourth Indian Fisheries Forum Proceedings $22^{\text {nd }}-28^{\text {th }}$ November, 1996, Kochi. 401-403.

Richu, A., N. Dahanukar, A. Ali, K. Ranjeet and R. Raghavan. 2018. Population dynamics of a poorly known serranid, the duskytail grouper Epinephelus bleekeri in the Arabian Sea. J. Fish Boil., 93(4): 741-744.

Samoilys, M., P. Amorim, J. H. Choat, C. Law, K. Ma, R. Myers, R. Nair, K. Rhodes, B. Russell, S. Suharti and A. To. 2018. Epinephelus malabaricus. The IUCN Red List of Threatened Species 2018: e.T61338A46627320. Downloaded on 20 November 2018.

Sekharan, K. V. 1962. On the oilsardine fishery of Calicut area during the years 195556 to 1958-59. Indian J. Fish., 9(2): 679-700.

Sivakami, S. and P. K. Seetha. 2006. Indiscriminate destruction of juveniles of spiny cheek grouper Epinephelus diacanthus (Valenciennes) off Quilon, Kerala. J. Mar. Biol. Ass. India, 48(1):128-130.

Sujatha, K., K. V. L. Shrikanya Rao and P. Padmavathi. 2010. Length-weight relationship of four species of Epinephelus Bloch, 1793 in the catches of Visakhapatnam, east coast of India. J. Mar. Biol. Ass. India, 52: 110-13. 